\title{
Representation of Gender Through Framing: A Critical Discourse Analysis of Hillary Clinton's Selected Speeches
}

\author{
Safina Kanwal ${ }^{1} \&$ Maria Isabel Maldonado García ${ }^{1}$ \\ ${ }^{1}$ Department of English Language and Literature, University of Management and Technology, Lahore, Pakistan \\ Correspondence: Safina Kanwal, Department of English Language and Literature, University of Management \\ and Technology, Lahore, Pakistan. E-mail: safina_kanwal@yahoo.com
}

Received: December 16, 2018 Accepted: January 19, 2019 Online Published: March 2, 2019

doi:10.5539/ijel.v9n2p321 URL: https://doi.org/10.5539/ijel.v9n2p321

\begin{abstract}
Foucault's theory of power and discourse has opened new horizons in the various fields of linguistics. It has brought the working of the power of discourse into the focus of research. Critical Discourse Analysis looks at this relationship between language and power. Language is taken as a patent tool for exerting power and for building identity (Foucault, 1998). Critical discourse analysis (CDA) reveals the ways by which discourse is manipulated for the construction of various domains such as identity, ethnicity, ideology, cultural differences and gender. The most wide-ranging and most influential work in CDA is of Norman Fairclough. He takes language as a social practice. He makes it clear that the power of discourse is used for depiction of ideology and gender representation. The present study used Critical Discourse Analysis (CDA) as an approach to find out the working of frames for representation of gender identity. The current study analyzed the campaign speeches of Hillary Clinton for finding out her projection of gender identity through frames. The data of the study consists of her opening primary campaign speech which is the Campaign Launch Speech and her last speech for Primary campaign that was delivered in the American presidential election of 2016. The theoretical framework for the present study is Fairclough's Three Dimensional Model (2015) and the tool applied on this model for looking into the working of frames is the Frame Problem Tool of Gee (2014). The results of the study revealed that Hillary used the technique of framing for projecting her gender identity. She used the fight and family frames for the modification of the boundaries of American presidency with respect to gender. Through her political discourse she framed herself as a brave and bold woman who had she become the president of the United States would have fought for the rights of all Americans irrespective of their creed, sect, religion, gender and nationality.
\end{abstract}

Keywords: critical discourse analysis (CDA), framing, gender, discourse, family

\section{Introduction}

The modern world is one of dramatic changes. It is the world of new perceptions and new representations of the realities of the past. This new perception has put a remarkable and vivid impact on women and feminism. Women have realized their worth and are actively participating in all the domains of life. They are no more timid and taboo holding. Rather, they are breaking all the past taboos and boundaries imposed on them. Like the woman of Maya Angelou's poem 'Woman Work', the woman of 21st century is looking beyond the four walls of her home. She wants to be free and take solace from participating in the activities of society. This realization of gender identity and the active role of women in the world are much evident in politics too. Women are actively participating in politics on one hand and on the other hand they are breaking the taboos of conservatism. America is also one of those countries where the participation of women in political activity has been increasing with the passage of time. The last American presidential election is a crystal clear proof of this new perception. Hillary Clinton pushed all the boundaries of American Presidency in regards to gender by becoming the first female official candidate for American Presidency of a political party.

Hillary Diane Rodham Clinton (October 26, 1947) is the first woman nominated as presidential candidate by a U.S. major political party, i.e., the Democratic Party. Clinton has set the role of a modern political spouse. She was the 67th United States Secretary from 2009 to 2013. From 2001 to 2009 she was a junior United States Senator. She remained the First Lady of United States from 1993 to 2001when her husband, Bill Clinton was the president of the United States. She was also the First Lady of Arkansas during the governor tenure of her 
husband from 1979 to 1981 and 1983 to 1992 . Her presidential campaign of 2016 was her second campaign for presidency. Although in 2008 she lost her run for presidency, yet in 2016 she was the most powerful candidate for presidency. Though Hillary was unable to succeed in the election, she was the most expected candidate for presidency. Moreover, she had a lead of 2.5 million voters over her contestant i.e., Trump. This lead of Democrats in this election is greater than the lead gained by the 10 previous presidents of the United States of America. Hillary won the popular vote and this shows that she has built her own positive image and made clear that a woman can be the president of one of the most powerful countries of the world. Her failure was not due to the number of votes, rather she failed in becoming the president of the United States of America due to the American system of presidential election. Nevertheless, she has not only changed the existing narrative of American Presidency for her gender, but also presented her gender as a strong, much determined and more family oriented compared to men (Lee \& Lim, 2016). She used the technique of framing for the representation of women through her political discourse. The present study is a critical discourse analysis of her Campaign Launch Speech and her last speech before the official announcement was made which named her as the Party Nominee of the Democratic Party for the American presidency.

In her political discourse she used the fight and family frames for representing herself as the true and right nominee for American Presidency. Through these frames she not only constructed a woman's identity as a very strong and emotionally composed human being but she also made clear to the world that the modern woman still gives top priority to her family and family values. For the woman of today, both social and family life are of great significance, though when it comes to the question of family and family values she would prioritize family and family values.

\subsection{Purpose of the Study}

Man is a social animal. Living alone is not an option in today's world. He needs company and for this purpose he uses language to develop and structure his relations with others. The words that we all use are never neutral (Fisker, 2009). These words not only carry their surface meanings but also have much deeper meanings. For Siddique (2014) language is a complex set with many social, political, cultural and symbolic implications. Thus through language we not only express our views about the world but also exert power and build identity through language (Foucault, 1998). The purpose of the current study is to investigate the role of framing for the projection of gender identity. For this purpose the technique of framing is used for evaluating the primary campaign speeches of Hillary Clinton.

\subsection{Objectives of the Study}

The present research has the following objectives:

1) Application of Fairclough's Three-Dimensional Model for analyzing the projection of Hilary Clinton's gender identity through her discourse.

2) To investigate the role of frames for the projection of gender identity in Hillary Clinton's speeches.

\subsection{Research Questions}

1) What are the different frames used by Hillary Clinton in her political discourse?

2) How is framing used for gender representation in Hillary Clinton speeches?

\section{Literature Review}

Critical Discourse Analysis is a multidisciplinary approach to language. It studies the relationship between language, power, ideology and identity. This approach to language is the latest version of Critical Linguistics and Discourse Analysis. In Critical Discourse Analysis the terms 'Critical' is the result of Marxism, Post-Structuralism and Deconstructionism that became popular after 1979. These notions became the center of research in the 20th century when linguists and philosophers started taking language as a source for expressing meanings that already exist in linguistic system and these meanings work within that system. This term 'Critical' becomes the basis of 'Critical Theory', 'Critical Literacy' and 'Critical Applied Linguistics'. Habermas (1984) established the very concept of 'critical'. For him critical studies are self-reflective as they provide the interest on which they are based. Thus the theories based on the notions of 'critical' and 'criticality' aim to provide clarification and liberation. This notion of being 'critical' is the heart and soul of linguistics and language study. Wodak (1999) defines 'critical' as "having distance to the data, embedding the data in the social, taking a political stance explicitly, and a focus on self-reflection as scholars doing research". She takes 'critical' as a "socially transformative process" with the help of which various objects and situations are judged and explained within their systems. Fairclough takes this notion of 'critical' in much broader way. For him 'critical' means 
highlighting the hidden "connections and causes" (1995, p. 747). This 'critical' notion gave birth to criticality in language and linguistics and ultimately it became the research agenda of many disciplines of linguistics. In this way "critical" in discourse analysis looks at the hidden relations between text and social conditions, text and ideologies and text and power relations.

Critical Discourse Analysis (CDA) is the developed branch of Critical Linguistics (CL) which emerged as a new branch of linguistics in late 1970s (Van Dijk, 2008). This branch of linguistics is also named Critical Language Awareness and Critical Language Studies. Systemic Functional Grammar given by Halliday became the basis of Critical Linguistics. Halliday's (1978) approach to language study provides three functions of language which are ideation function, interpersonal function and textual function. Fairclough (1995) takes ideation function of language as the experience of the speaker about the world and various phenomenon of the world, whereas the interpersonal function of language refers to the speakers' attitudes, beliefs and evaluations about the world and the textual function of language is that the speakers produce such type of text which can be understood by listeners. Thus, the textual function of language connects the discourse with its context and this idea of connecting text with its context makes language a "social act" which later became the basis of many researches (Chouliaraki, 2000; Fairclough, 1989, 1992, 1993, 1995) and it laid the foundation of critical discourse analysis (CDA).

Raising consciousness as the principal aim of Critical Linguistics has paved the way for Critical Discourse Analysis. This school of Critical Discourse Analysis (CDA) took its present name and form in early 90's from the fields of rhetoric, pragmatics, applied linguistics, text linguistics, semiotics and socio-linguistics. The chief founders of this school of thought are Norman Fairclough, Ruth Wodak, Teun Van Dijk, Gunther Kress and Theo Van Leeuwan. Van Dijk defines Critical Discourse Analysis as "one school of thought that relates this aspect of the 'critical' to the notion of dominance, which is defined as the exercise of social power by elites, institutions or groups, that results in social inequality, including political, cultural, class, ethic, racial and gender inequality" (1993, pp. 249-250). Thus CDA aims at highlighting those textual experiences that are done through the power of discourse. According to Fairclough $(2013$, p. 5) the purpose of engaging in critical discourse analysis is not just to analyze, but to criticize what is happening through discourse and its ultimate goal should be to bring changes in society.

Discourse is an integral part of Critical Discourse Analysis. But what is discourse? Discourse is often taken as synonym of language. It is language but not just language. It is a social process. It is "language in its relations with other elements in the social process" (Fairclough, 2015, p. 8). Discourse comes under the umbrella of the relational view of language. Paltridge (2013) says that as language use is structured within particular situations, institutions and social set up, thus discourse produced in every context is shaped by these factors. Through discourse people construct beliefs, institutions and social relations. Discourse includes multi semiotic texts. In CDA the focus is on language because it is the most important semiotic form. CDA critiques discourse (Fairclough, 2015, p. 9). It not only interprets, evaluates and critiques discourse but also explains discourse. Language and society are part and parcel of each other. There is no one to one relation between language and society. The relation between language and society is both internal and external. Society is a whole and language is one of the strands of society. Language is critical when portraying gender. There are languages like the Romance languages which do have a grammar feature called the "grammatical gender" which has been the object of review of the local language academies (Maldonado Garcia, 2015).

There exists a dialectic relation between language and society. Fairclough (1998, p. 135) believes that language is directly connected with social realities and it is the very cause of social changes that take place in any society. $\mathrm{He}$ is of the opinion that governments often manipulate language through discourse for linking their ideology and power relations in society. His approach to language is deeply rooted in Halliday's Systemic Functional Grammar. He laid stress on taking text as the outcome of a process in which discourse takes part in the construction of various social structures that are involved in the process of production and interpretation of the text. His model of Discourse Analysis functions on this dialectic relationship between the micro and macro structures of discourse. The macro-structures of society are often involved in determining the micro-structures of discourse.

The founder of CDA take it as an approach having different multiple and competing methodologies and theories the aim of all of which is to bring social change and social consciousness. Fairclough and Wodak (1997, pp. 271-280) have briefly summarized the major goals of CDA in the following points:

- CDA addresses social problems

- Power relations are discursive 
- Discourse constitutes society and culture

- Discourse is historical

- The link between text and society is mediated

- Discourse analysis is interpretative and explanatory

- Discourse is a form of social action

Fairclough major contribution to CDA is his three dimensional model which first appeared in (1989) in his book entitled 'Language and Power'. In 2015 he revised his book and also revised the model. According to this model the analysis of data consists of three stages. Among the three stages or layers of this model the first layer is the text, the second layer is interaction and the third layer is the context. The first step of analysis which is text involves the description of the "formal properties of the text", the second step is the interaction which is the interpretation of the "relationship between text and interaction", and the third step is context which is an explanation of the "relationship between interaction and social context" (Fairclough, 2015, pp. 58-59). Fairclough (2015, p. 169) defines frame as a "representation of whatever can figure as a topic, or 'subject matter', or 'referent' within an activity". Lakoff (2004) defines frames as "mental structures that shape the way we see the world". Frames are ideologically variable and those who are powerful change and develop their frames for attaining their own specific goals. Thus frames "represent the entities which can be evoked or referred to in the activities represented schemata" (ibid).

Hillary Clinton's political speeches are the data of the present study. She ran for the American presidency on behalf of the Democratic Party. A political party or group is joined by common ideas and opinions on various aspects in society. That is the reason why political groups have their own language and portray themselves through their own discourse. They signal their ideology through certain slogans (Wodak, 1989). Since ideologies are embedded in one's discourse George Lakoff in his book Moral Politics (2016) spoke about viewing American society and their politics through the Family Models. He came up with two types of family model regarding American politics. The first is The Strict Father Model and the second is The Nurturant Parent Model. The Strict Father Model is a reference to the world-view of the Conservatives. Metaphorically speaking this model portrays the ideal order of society according to the Republican Party. Basic Postulates are: discipline, exercise of authority is itself morality, reward and punishment, boundaries and self-interest. The Nurturant Parent Model is a reference to the world view of the liberals and the Democrats. This model is an interpretation of a more modern interpretation of the nuclear family. This model works on the following principles: empathy, nurturance, self-nurturance, social ties and fairness. While engaging in the critical discourse analysis of Hillary's speeches this model is also taken into consideration.

Fisker (2009) conducted a study on the concluding democratic presidential debates of 2008 between Hillary Clinton and Barak Obama. The results of the study indicate that both Clinton and Obama have used discourse to gain power. They used intertextuality and interdiscursivity to bring the opponent into hot water during their debates. They used intertextuality as a major tool for gaining power through discourse and for constructing the Democratic ideology. Moreover, Clinton identified herself with American women and built her gender identity as well through discourse. They both used different modes of persuasions to build their positive image. Shayegh and Nabifar (2012) conducted research on Obama's interviews from the perspective of ideological and socio-political relations of power. They used systemic functional grammar for critical discourse analysis. The analysis of the data shows that Obama used simple words, short sentences, material processes, modality, transitivity, and present simple and future simple sentences. The data revealed that Obama employed discourse as a tool for exerting power through his use of religious references, persuasions, and future's plan statements.

Abdel-Moety (2015) conducted a research study on Hillary Clinton's interviews to look into the relation between power and language, characteristics of Clinton's political discourse and to explore the hidden strategies used by her for the representation of her political ideology. The results of the study revealed that she uses language very strategically and often employs rhetorical strategies of persuasion. Besides these she uses certain linguistic devices for obtaining power in discourse and also for power over discourse.

There seems to be a growing body of studies on CDA. In surveying the recent annals of literature, some other considerable studies have also inspected various political, advertisement, media etc. discourses in light of CDA to discern multiple strategies utilized by orators and political pundits and to show how language users make the text/talk persuasive, significant, appealing and obscure, as well as how they convey their intended objectives to the audience (Kazemian \& Hashemi, 2014, 2017; Ali \& Kazemian, 2015; Ali, Kazemian \& Bughio, 2015; Amoli, 2016; Carreon \& Svetanant, 2017; Gill \& Kausar, 2017). Prior studies have tended to concentrate on some other 
genres and discourses. This study is unique in the sense that it attempts to bridge the gap among previous studies by investigating Hillary Clinton's Selected Speeches in the light of CDA to find Representation of Gender through Framing.

\section{Methodology}

Hillary Clinton's political speeches are the data of the present study. A political party or group is joined by common ideas and opinions on various aspects in society. That is why political groups have their own language and portray themselves through their own discourse, they signal their ideology through certain slogans (Wodak, 1989). As ideologies are embedded in one's discourse so for viewing American society and their politics the Family Models given by George Lakoff in his book Moral Politics (2016) are taken into consideration. The first is The Strict Father Model and the second is The Nurturant Parent Model.

The current study is a qualitative study, focusing on the critical discourse analysis of Hillary Clinton's selected speeches. The theoretical framework for the present study is Fairclough's Three Dimensional Model (2015). The tool that is applied on this Model for framing is the Frame Problem Tool given by James Paul Gee (2014). The model below is the theoretical framework of the present study for critical discourse analysis:

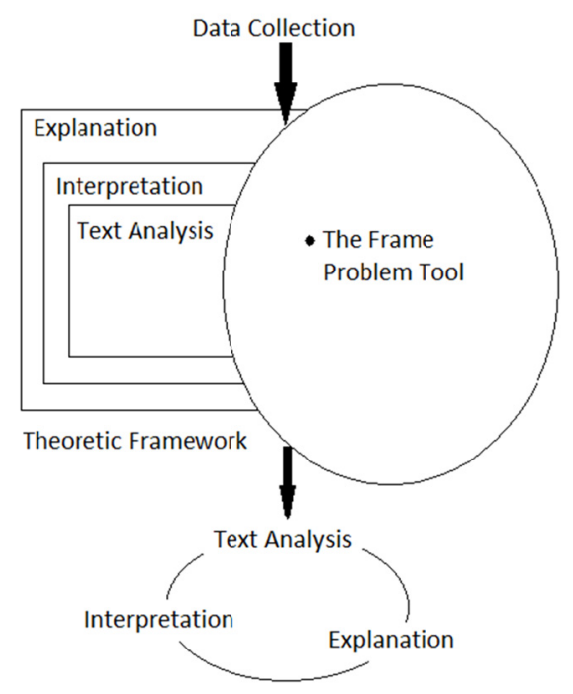

Figure 1. Methodology

\subsection{Data Collection}

The data for the present study consists of two speeches that Hillary Clinton delivered during her Primary Election campaign for 2016 American Presidency. The first speech is her Campaign Launch Speech that she delivered on 13th June 2015 at New York and the second speech is her last Primary Campaign Speech that she delivered on 13th July 2016 at Illinois. The rationale behind the selection of these two speeches is that they cover the total time of her Primary Campaign. Moreover the opening speech and the last speech are always very important speeches when a politician is running for election in general and for the election of President of a state in particular. These two speeches were downloaded from Hillary Clinton's official website: https://hillaryspeeches.com. The video recordings of these two speeches are available on YouTube as well so the researchers confirmed that the two versions are in fact the same. The model applied for data analysis is Fairclough's (2015) Three-Dimensional Model. The three dimensions and steps of data analysis in this model are as follow:

\subsubsection{Text Analysis}

The first dimension of this model is the description of the data. In this stage textual features of Hillary Clinton are evaluated. 


\subsubsection{Interpretation}

The second dimension is the presentation and interpretation of the data.

\subsubsection{Explanation}

The third dimension is the explanation of the data.

\section{Results and Findings}

As discussed in the literature review section of the article that framing is the technique of structuring reality. Throughout her primary election speeches during the election of 2016, Clinton has constantly used different frames for building her relations with her voters and also for projecting her identity as a woman. Through these frames she has presented herself as a very strong, laborious, family-oriented and committed woman endowed with all those qualities that are prerequisites to lead America for better future. Among these frames the most commonly used frames are fight frame and family frame.

\subsection{Fight Frame}

Hillary Clinton has used fight frame over and over again in her speeches. This becomes quite evident when we do the critical discourse analysis of her Campaign Launch Speech of 2016 Presidential Election. The whole speech is built on this fight frame. She presented her political ideology and her agenda for running the campaign of American presidency because she wanted to fight for the rights of Americans. She uses the word 'fight' in different contexts but the ultimate goal of using the word 'fight' is to build a frame of 'fighter' for herself and to make it realize to her audience that she is the only candidate for American presidency who has been fighting since a long time for the rights and betterment of all the people of America. She says to her audience:

"If you'll give me the chance, I'll wage and win four fights for you".

Here she uses the word "fights" for her political agendas. The word "fights" builds the fight frame for Hillary and projects her as a fighter and brave lady. The purpose of this use of the fight frame is actually an attempt to change the existing narrative of the American presidency for a female. In the United States there had never been a female selected as the official nominee for Presidency from a political party before. Though USA is one of the liberal and modern countries of the world yet it still has a very conservative society where women are not equally treated and they were never selected for the American presidency. That is why when in 2016 Hillary was running her campaign for the party nomination of the Democratic Party she had to fight for her gender identity as well. So right from her Campaign Launch Speech she has projected herself as a strong woman who will fight for the people of America as she talks about her first fight in the opening part of her speech:

"The first is to make the economy work for everyday Americans, not just those at the top".

The above lines make it clear that Hillary wants to fight not for a particular class or section of the society rather for all the people of America. This use of the word "fight" builds the fight frame for her and she makes it clear to her audience as well as to all the Americans that she is such type of woman who is capable of fighting for the betterment of the people of her country. She will fight for their economic development and this economic development will enable Americans in becoming strong and well established. She talks about her second agenda for running the campaign for American presidency in the following lines:

"Now, the second fight is to strengthen America's families, because when our families are strong, America is strong".

Here, again Hillary uses the word "fight" for her political agenda which is to fight for strengthening American families. In this case, she is not only building the fight frame for herself but is also relating this fight frame with the family frame so that she makes all American families realize that she is fighting for them. She tries to get support and vote of maximum number of voters through this fight frame and family frame. The third agenda of her election is again projected through fight frame as Hillary talks about it in the following words:

"So we have a third fight: to harness all of America's power, smarts, and values to maintain our leadership

for peace, security, and prosperity".

In the above lines the interesting thing is that here she has built her solidarity with her audience through this fight frame. She uses the pronoun "we" with noun "fight" and has made herself as well as her audience as the agent of the action of fighting. This solidarity is also seen in the fourth agenda of Hillary where she says that she along with Americans will fight for democracy that can work for everyday Americans. She says it in the following part of her speech:

"That's why we have to win the fourth fight-reforming our government and revitalizing our democracy so 
that it works for everyday Americans".

Here again Hillary is bringing her audience under the fight frame as she uses the inclusive pronoun "we" for the fourth fight of her political agenda. She is making this fight compulsory both for herself and her audience by using the auxiliary "have to" with the verb "win" and ultimately establishes her identity as a strong, determined and brave female who always supports her people and whose motive for becoming the American president is to fight for that sort of democracy which will work for the "everyday Americans", in reality, the middle and lower classes. In this way, Hillary built her gender identity as a very brave and bold candidate for the American presidency and projected herself as a female fighter ready to "wage and win four fights" for them.

In her last primary campaign speech that Hillary delivered on 13th July 2016 at Illinois she again used the fight frame for projecting her identity and ideology. Throughout her campaign speeches she relied much on this fight frame as she wanted to push out the boundaries of the American presidency with regards to gender. For this purpose she presented herself as a fighter again. Mostly when she talked about her policies and political ideology she built her personality through the fight frame. At Illinois while talking about her future plans as president she says:

"So, too, we must fight inequality and create opportunity in our time, not for some Americans, but for all. So, I come today as a mother, and a grandmother, to two beautiful little children, who I want them and all of our children to grow up in a country where violence like the kind we saw last week doesn't happen again".

She uses the fight frame not only for herself but also for her audience and here the fight is made obligatory by Hillary as she uses "must" with fight. She invokes her supporters to be in her fight against the inequality prevailing in American society. She relates this fight frame with her gender identity as in the very next sentence she projects herself as "mother" and "grandmother". Moreover, she uses the world "our children" for all the children of America. In this way, she puts herself at two levels: One, the protector of all children, the savior from inequality and the creator of opportunity and two, at the same time makes herself equal to the rest of the females of the American society.

\subsection{Family Frame}

With the fight frame, Hillary also uses the family frame in her campaign speeches over and over again. For her family life and institution of family is of great significance. She often relates the family issues with social issues. That is why in her first speech for the 2016 presidential election i.e., her Campaign Launch Speech while talking about her second plan as a president she says:

"Now, the second fight is to strengthen America's families, because when our families are strong, America is strong".

She makes it clear to her audience that, for her, America can only be strong when all the American families will be strong. For her America and all the American families are one and the same thing, since countries are made by people and people belong to families. In this way she projects her gender identity as a loving mother for whom all the members of her family are of equal importance. Looking from Lakoff's family model's perspective Hillary and her political ideology is based on the Nurturant Parent Model.

The projection of female identity becomes quite apparent when Hillary in her Campaign Launch Speech talked about the problems of working women. She pointed out that in America women are still earning less as compared to men working in the same job. Her intention was portrayed as to fight for women and their issues as she related this matter of women with the family frame like this:

“This isn't a women's issue. It's a family issue. Just like raising the minimum wage is a family issue. Expanding childcare is a family issue. Declining marriage rates is a family issue. The unequal rates of incarceration are a family issue. Helping more people with an addiction or a mental health problem get help is a family issue".

In the above part of her Campaign Launch Speech Hillary relates all the female issues with family issues and embedded the problems women face as a part of the family frame. In this way, she is built her family frame as one in which women are treated equally and will never be ruled by men, rather, they will be honored and achieve whatever they wish or they want to become. This becomes clearer when in the last lines of her speech she talks about her vision of America as a country:

"An America where a father can tell his daughter: yes, you can be anything you want to be. Even President of the United States". 
In Hillary's family frame she makes all the families as a part of her family. This works well for matters such as immigration and illegal citizens. This converts into effective speech techniques targeted towards the different issues of the American people. That is why she made it part of her political agenda to provide citizenship even to all the noncitizen families living in America shall she become President, which is quite against the policies of her opponent party. She says:

"So we should offer hard-working, law-abiding immigrant families a path to citizenship. Not a second class status".

Thus, inclusion of all the families in her American family frame helped Hillary to achieve the support of all those families which have been neglected by all the past presidents of America; these are perhaps the legal immigrants with family members who are still illegal. Moreover, this family frame built by Hillary projects Hillary's identity as a very loving and caring female candidate for American presidency who wants to fight for the rights of all those who were never given due rights. A mother to all Americans. In this regard the LGBT community cannot be forgotten. She talks about them in the following lines:

"And, we should ban discrimination against LGBT Americans and their families so they can live, learn, marry, and work just like everybody else".

LGBT Americans are not accepted for the rigid orthodox Christians (which are usually Republican) and for the Republicans in general. They are bitterly criticized by most of the Americans who believe in old values. However, the Republican Party has traditionally supported minorities. Hillary breaks those boundaries and wants to ban all sort of discrimination against them. She makes them part of her family frame and projects her identity as a soft and loving female who is the only right choice for the great majority of Americans. She again relates her family frame with the fight frame as in the following lines while talking about making the American family strong: "Like any family, our American family is strongest when we cherish what we have in common, and fight back against those who would drive us apart".

Thus, she makes it clear to her voters and audience that she will fight against all those who are driving apart American family. This handling of both family and fight frame in the same sentence projects Hillary as a woman, who like any woman, has strong believe in the institution of the family (which is basically the basis of the Republican agenda) but she is not frail like the women of the past. On the contrary she is bold and brave and is ever ready to fight against all those who drive the family institution apart.

This use of the family frame is part and parcel of Hillary's all campaign speeches. In her last primary campaign speech she talked about families and their problems as one of the major issues that she will tackle first after becoming the president. On July 13, 2016 in her speech at Illinois, which was her last primary campaign speech she talks about her firm belief in America as a one family and her belief in unity of all American families as she says:

"My life's work is built on the conviction that we are stronger together, not separated into factions or sides, not shouting over each other, but together".

In this way through her family frame she builds her identity again as one who cares about all the families living in America. Indirectly, she indicates that America needs such President who will pull all the Americans together instead of splitting them apart as she says in the following lines:

"We need a president who can help pull us together, not split us apart".

Here she uses collective inclusive "we" for including her audience. She is of the opinion that it is not her need rather the need of all Americans that their future president will be a driving force who will make them united. The following lines also help us understand Hillary's family frame where she includes all the family problems as well as minorities as the key agendas of her campaign:

"We need to listen to the families whose loved ones have been killed in police incidents".

"We need to listen to those who say 'black lives matter".

Above she mentioned the problems of race.

Further, relates the economical problems with family problems as it is the duty of a state to provide equal opportunities of earning and economic prosperity to all of its citizens. Moreover, from her point of view, economic reforms and policies of a country must work for all the people not for those who are already richer than the others. About this thing she says:

"We do need to make sure our economy works for everyone, not just those at the top". 
In the above line, Hillary used the inclusive "we" for obtaining the support of her audience and also for building the relationship of solidarity with her voters. Moreover, she wanted to make it clear to her audience that it is their needs she will target and that is why she made them her needs. Also the economy must work for everyone. In this way through the family framing Hillary projects her identity as a very loving and caring candidate for the American presidency for whom the family institution and all its problems are a priority, which is usually the basis of the Republican agenda.

\section{Discussion}

On the basis of the above analyzed data it can be said that Hillary Clinton's primary campaign speeches for American presidency are of great significance from a critical discourse analysis point view. Through her speeches she built different frames and through these frames she had not only projected her ideology but also presented her gender identity. The most commonly used frames in her speeches are the fight and family frames. The existing fight frame, in most of the societies of the world and in the American society in particular portrays men as fighters and brave who engage in foreign as well as local issues to solve. But Hillary has built her own fight frame in which a woman can equally fight for the welfare and betterment of her society. She tried to change the existing American narrative for American presidency where a woman in the past could never be selected as the official nominee from any political party with respect to gender. She sets this narrative of presenting her gender identity as a strong and brave woman since her first speech. Her Campaign Launch Speech is structured on this fight frame as well as all her agendas for running the race of American presidency. She uses the statement "four fights" to indicate the main issues she would have targeted should she had become the President. She wished to be the president of not a few Americans, like the Republican Party. Rather, she differentiated herself by becoming an open minded President of all the people of America irrespective of their gender, creed, religion, sect and even nationality. She built her identity to differentiate herself from the projection of women the opposition created. She related herself with her audience and all the Americans in her fight for the due rights of her nation equally. This can be seen in her constant use of the inclusive "we" for her fight and invoked her audience to fight with her for achieving their due rights in the world and most specifically in the United States.

The data shows that through her discourse Hillary has used effective tactics to convince her audience and all the Americans to the fact that although she is a woman, she had the strength and vigor required to become the future president of America.

The family frame is also used sparingly by Hillary in her campaign speeches. The motive behind using the family frame is to achieve a sense of unity in the American society, for various reasons. It is the agenda of the Democratic Party to include the minorities in their pool of voters and she achieved this target by infusing a sense of unity and equality and by introducing herself as the "mother" and protector of all sections of society, including Republicans. Her framing of "her" family is liberal and basically the opposite of the family frame of her opponent party. In her speeches she pushed the boundaries of the family frame (from the existing American concept of family which is traditionally white and Christian, heterosexual and nuclear) to the inclusion of all the people who are living in the United States, though they may be black, Hispanic, of Asian descent, Muslims, noncitizens, and even the LGBT Community. All of these types of people are included in her concept of Americans.

She portrays her feminist side as well by bringing all of the issues of women as family issues and ultimately as the issues of the country. When observed from Lakoff's Family Model's perspective, Hillary and her ideology fall under the Nurturant Parent Model where the head of family must not only be the male member of family but can also be the female member. Moreover, in the Nurturant Parent Model the head is very caring and the all the members of family are of equal importance. Hillary's liberal stances of the family frame also prove that she is a reflection of the head of Nurturant Parent Family Model and for her to become the president of the United States means to become the head of the American family, as an united nation. That is why again and again she reiterates "America can't succeed unless you succeed" where the pronominal "you" means all of the people who live in America and she was not running for some Americans, but for all Americans.

\section{Conclusion}

To conclude based on the data analysis, it becomes quite evident that Hillary Clinton had used the technique of framing for projecting her gender identity in her 2016 Primary Campaign speeches. Through the fight frame she had not only metaphorically built her identity as a brave and courageous woman but also pushed the boundaries of American presidency with respect to gender. In the traditional American presidency frame, there was no concept of a woman becoming the president of America or the official presidential nominee of a party but Hillary changed this concept by becoming the first female as the official presidential nominee of the Democratic Party. 
At the end, she was unable to become the president of the United States yet she achieved a much higher number of popular votes as compared to her opponent Donald Trump. In this way, language assisted her to become a very tough candidate for the opposition. She is the voice and choice of most of the Americans. She very tactfully and strategically used the fight frame and family frame for the projection of her gender identity and for achieving the vote of her audience. She used the power of discourse to project her identity as a strong and valiant female leader who had all the qualities to become the president of the United States.

\section{References}

Abdel-Moety, D. M. (2015). American Political Discourse as Manifested in Hillary Clinton's Interviews: A Critical Approach. English Linguistics Research, 4(1), 10-23. Retrieved from http://www.sciedupress.com/journal/index.php/elr/article/viewFile/6136/4005

Ali, S., \& Kazemian, B. (2015). Critical Discourse Analysis of a Reading Text 'Pakistan and the Modern World': A Speech by Liaquat Ali Khan. Communication and Linguistics Studies, 1(3), 35-41.

Ali, S., Kazemian, B., \&Bughio, F. A. (2015). An investigation of the reading text 'Pakistan Zindabad' (Long Live Pakistan): Critical discourse analysis perspective. Education and Linguistics Research, 1(2), 42-51.

Amoli, F. A. (2016). The Effect of Fairclough's Approach in Iranian Literacy Texts: Critical Discourse Analysis $\begin{array}{llllll}\text { Perspective. Mediterranean Journal of Social } & \text { Sciences, } & 7(4), & 658 .\end{array}$ https://doi.org/10.5901/mjss.2016.v7n4p658

Carreon, J. R., \& Svetanant, C. (2017). What Lies Underneath a Political Speech? Critical Discourse Analysis of Thai PM's Political Speeches Aired on the TV Programme Returning Happiness to the People. Open Linguistics, 3(1), 638-655. https://doi.org/10.1515/opli-2017-0032

Chouliaraki, L. (2000). Political discourse in the news: Democratizing responsibility or aestheticizing politics? Discourse \& Society, 11(3), 293-314. https://doi.org/10.1177/0957926500011003002

Fairclough, N. (1989). Language and power. London and New York: Longman.

Fairclough, N. (1992). Discourse and social change. Cambridge: Polity Press.

Fairclough, N. (1995). Critical discourse analysis. London: Longman.

Fairclough, N. (2013). Critical discourse analysis: The critical study of language. Routledge. https://doi.org/10.4324/9781315834368

Fairclough, N. (2015). Language and power (3 uppl.). London \& New York: Routledge.

Fairclough, N., Jessop, B., \& Sayer, A. (2004). Critical realism and semiosis. In J. Jospeh \& J. Roberts (Eds.), Realism, Discourse and Deconstruction (pp. 23-42). London: Routledge.

Fisker, S. L. M. (2009). Power in discourse: A Critical discourse analysis of the concluding democratic presidential debates 2008. Retrieved June 8, 2016, from http://projekter.aau.dk/projekter/files/18011253/2009-08-03_10.29.28.pdf

Foucault, M. (1998). The History of Sexuality: The Will to Knowledge. London, Penguin.

Gee, J. P. (2014). How to do discourse analysis: A toolkit. Routledge. https://doi.org/10.4324/9781315819662

Gill, A. A., \& Kausar, G. (2017). Game of hope and doubt: critical discourse analysis of pak-china economic corridor. New Horizons, 11(2), 1-109.

Habermas. (1984). The theory of communicative action (Vol. I). Boston: Beacon.

Halliday, M. A. (1978). Language as social semiotics. London: Edward Arnold Publisher.

Kazemian, B., \& Hashemi, S. (2014). Critical discourse analysis of Barack Obama's 2012 speeches: Views from systemic functional linguistics and rhetoric. Theory and Practice in Language Studies, 4(6), 1178-1187. https://doi.org/10.4304/tpls.4.6.1178-1187

Kazemian, B., \& Hashemi, S. (2017). A Radical Shift to a Profound and Rigorous Investigation in Political Discourse: An Integrated Approach. International Journal of English Linguistics, 7(3), 115-128. https://doi.org/10.5539/ijel.v7n3p115

$\begin{array}{llllll}\text { Lakoff, } & \text { G. (2016). } & \text { Moral } & \text { Politics. }\end{array}$ https://doi.org/10.7208/chicago/9780226411323.001.0001

Lakoff, R. T. (2004). Language and Woman's Place: Text and Commetaries: Rev. and Expanded Ed. Oxford University Press. 
Lee, J., \& Lim, Y. S. (2016). Gendered campaign tweets: the cases of Hillary Clinton and Donald Trump. Public Relations Review, 42(5), 849-855. https://doi.org/10.1016/j.pubrev.2016.07.004

Maldonado Garcia, M. I. (2015). Spanish "Politically Correct" Movement: Reasons for Failure. Journal of Political Studies, 22(I), 237-252

Paltridge, B. (2013). Critical Discourse analysis. In K. Hyland (Ed.), Discourse studies reader: Essential excerpts (pp. 89-109). London: Bloomsbury Academic.

Shayegh, K., \& Nabifar, N. (2012). Power in political discourse of Barak Obama. Journal of Basic and Applied Scientific Research, 2(4), 3481-3491.

Siddique, S. (2014). Language, Gender and Power: The Politics of Representation and Hegemony in South Asia. Karachi: OUP.

Van Dijk, T. A. (1993). Principles of critical discourse analysis. Discourse \& Society, 4(2), 249-283. https://doi.org/10.1177/0957926593004002006

VanDijk, T. A. (2008). Discourse and Power. New York: Palgrave Macmillan. https://doi.org/10.1007/978-1-137-07299-3

Wodak, R. (Ed.). (1997). Gender and discourse. Sage.

Wodak, R. (1999). Critical discourse analysis at the end of the 20th century. Research on Language \& Social Interaction, 32(1-2), 185-193. https://doi.org/10.1207/S15327973RLSI321\&2_22

\section{Copyrights}

Copyright for this article is retained by the author(s), with first publication rights granted to the journal.

This is an open-access article distributed under the terms and conditions of the Creative Commons Attribution license (http://creativecommons.org/licenses/by/4.0/). 